\title{
ROHINGYA CRISIS IN BANGLADESH-THE EFFECT OF ETHNIC CLEANSING IN MYANMAR
}

Rohingyas are the most persecuted communities in the world. Since August 25, Myanmar has sharply escalated its systematic assault against a Muslim minority people called the Rohingya, in a ravaging campaign of murder and rape which the top United Nations human rights official considers a "textbook example of ethnic cleansing ${ }^{1}$. Over 200 villages have been burned and destroyed. Acts of brutality, namely killings, disappearances, torture, and sexual violence is done Myanmar army. Myanmar discriminated Rohingyas on the basis of name, different look and religion.

Despite the fact they've lived in Myanmar for generations but the government denies citizenship to the downtrodden Rohingya and scornfully calls them "Bengalis". Myanmar's Buddhist majority despising them as terrorists or illegal immigrants from Bangladesh.

The idea of disaster is usually associated with human suffering caused by natural events: tsunamis, hurricanes, earthquakes, ûoods. However, humancreated disasters stemming from war, the conduct of repressive regimes, the use of sanctions, and economic and social policies represent an equally important dimension of disaster. These practices have political goals and produce a range of negative social and economic conditions beyond their stated aims. They cause human suffering, especially among vulnerable groups, disproportionately women, children, older people and poor people ${ }^{1}$. The UN Secretary-General reports shortages of food, potable water, shelter, and access to medical care for these new arrivals. $2,3,4,5$

Since $25^{\text {th }}$ August 2017, total forcibly displaced Myanmar national to Bangladesh is 622000 . $40 \%$ of the total remain in 3 settlements Balukhali, Leda \&Kutupalong makeshift settlements. Identified vulnerable people are $10.6 \%$ of population. Among them, pregnant mothers $3 \%$, lactating mothers $7 \%$, disabled persons $0.4 \%$, unaccompanied and separated children $0.2 \%$ and elderly $4 \%$ of population. Disease profile among the displaced Myanmar nationals (Rohingya) are diarrhea 21254(38.6\%), respiratory tract infection 3064 (5.6\%), cough and cold/ no pneumonia 15579 (28.3\%), skin disease 7921 (14.4\%), injury 1369 $(2.5 \%)$, abscess 1105 (2\%), eye infection 2813 $(5.1 \%)$, severe acute malnutrition $701(1.3 \%)$,moderate acute malnutrition $1255(2.3 \%)^{2}$. Besides these, STD 265, unexplained fever 112598, neurological disorder 218, malaria test positive 13752 , measles 611 cases were identified. A total of 804 suspected diphtheria cases including 15 deaths were reported among the displaced Rohingya population in Cox's Bazar ${ }^{6}$

Government also started vaccination among the vulnerable group like MR, OPV, Vitamin A capsule, Cholera vaccine. 237,500 children immunized against measles and rubella. 900,000 doses of OCV administered in two rounds. 650,000 affected people vaccinated against cholera ${ }^{6}$.

Huge logistic and manpower is required to provide health service to the diseased Rohingya. Total 147 static health center (Government: 25, Army:10 and Non-Government: 112) is established. Total number of physicians and supportive staffs are 107 and 574 respectively. Total member of vaccination team is 231 and field ambulance number is 21 . Sanitation and safe drinking water is always a problem in disaster situation. 450,000 people provided with access to safe drinking water; culturally appropriate latrines; and key messages on hygiene ${ }^{6}$.

Disaster brings multiple types of stressors in disaster victims like bereavement, property loss and threat of life. Psychological problems mostly encountered are post-traumatic stress disorder,generalized anxiety disorder, night terror, phobic disorder, depression, bipolar mood disorder and psychosis.

The UN Security Council has responsibility to address both the massive humanitarian crisis underway in the region, and to determine if genocidal acts should be investigated. A full investigation into crimes against humanity and accountability for those crimes is deemed necessary. Impunity for mass killings cannot be allowed in this era.

\footnotetext{
Prof. QT Islam ${ }^{1}$, Dr. Md.Robed Amin ${ }^{2}$, Dr. Mohammad Rafiqul Islam ${ }^{3}$

1. Editor in Chief

2. Executive Editor

3. Assistant Editor
}

Bangladesh J Medicine 2018; 29 : 1-2

DOI: $h t t p: / / d x$.doi.org/10.3329/bjmed.v29i1.35400 


\section{References:}

1. Harding S. Man-made disaster and development The case of Iraq. International Social Work 50(3): 295306

2. Ramzy A. At risk in Rohingya crisis: 230,000 children, hundreds alone.The New York Times, Sept $16,2017$.

3. Beech H. Bangladesh to build huge new camp for the Rohingya. The New York Times, Sept 17, 2017.

4. UNICEF. 150,000 Rohingya children in Bangladesh to be vaccine amid threat of disease outbreak. Sept
17, 2017. https://www.unicef.org/media/ media_100846. html (accessed Sept 19, 2017).

5. World Food Programme. WFP Bangladesh country brief: challenges July, 2017. http://documents. wfp.org/stellent/groups/public/documents/ep/ wfp273241.pdf?_ga= 2.250217414. 190577474. 1505836548-1267525239. 1505836548 (accessed Sept 19, 2017).

6. Directorate General of Health Services (DGHS). 2017. Health Bulletin 2017. Dhaka: Ministry of Health \& Family Welfare. 